\title{
Hemşirelik Birinci Sınıf Öğrencilerinin Beceri Uygulama Sınavındaki Sınav Kaygısı ve Problem Çözme Becerileri Arasındaki İlişkinin İncelenmesi
}

\author{
Banu Terzi $^{*}$, Gözde Yıldız Daş Geçim² ${ }^{2}$ İbrahim Topuz ${ }^{2}$ \\ ${ }^{1}$ Akdeniz Üniversitesi Hemşirelik Fakültesi, Hemşirelik Esasları Anabilim Dalı, Antalya Türkiye, \\ ${ }^{2}$ Amasya Üniversitesi Sağlık Bilimleri Fakültesi, Amasya Türkiye \\ email: copurbanu@hotmail.com, hemyildiz@hotmail.com,ibrahimtopuz_38gs@hotmail.com \\ Orc1d:0000-0002-9500-6872 \\ Orcid:0000-0002-9147-2016 \\ Orcid:0000-0003-0540-2095 \\ *Sorumlu Yazar / Corresponding Author: Sorumlu Yazar: Banu Terzi \\ Gönderim Tarihi / Received:08.08.2019 \\ Kabul Tarihi / Accepted:12.11.2019 \\ DOI: $10.34087 /$ cbusbed.604108
}

\begin{abstract}
Amaç: Hemşirelik birinci sınıf öğrencilerinin beceri uygulama sınavındaki sınav kaygısı ve problem çözme beceri düzeylerini ve bunların ilişkisini incelemek amacı ile yapıldı.

Yöntem: Tanımlayıcı ve ilişki arayıcı tipteki araştırmanın örneklemini bir üniversitenin Sağlık Bilimleri Fakültesi hemşirelik bölümünde okuyan birinci sınıf öğrencileri $(\mathrm{n}=68)$ oluşturdu. Verilerin toplanmasında; Revize Edilmiş Sınav Kaygı Ölçeği ve Problem Çözme Envanteri kullanıldı. Araştırmanın verileri 2018 tarihinde toplandı.

Bulgular: Öğrencilerin sınav kaygısı toplam puan ortalamasının 41,04 $\pm 9,60$ (Min.=24-Mak.=66), problem çözme toplam puan ortalamasının 87,82 $\pm 17,15$ (Min.=46-Mak.=127) olduğu saptandı. Problem Çözme Envanteri'nin Aceleci Yaklaşım, Düşünen Yaklaşım alt boyutları ve toplam puanı ile Revize Edilmiş Sınav Kaygı Ölçeği'nin Sınavla İlgisiz Düşünceler alt boyutu arasında istatistiksel anlamlı zayıf ilişki olduğu belirlendi $(p<0,05)$. Ayrıca erkek öğrencilerin kızlara göre istatistiksel anlamlı farklılıkla endişe boyutunda daha fazla sınav kaygısı yaşadıkları ve problem çözmede daha aceleci oldukları bulundu $(\mathrm{p}<0,05)$.

Sonuç: Hemşirelik birinci sınıf öğrencileri beceri uygulama sınavı sırasında orta düzeyde sınav kaygısı yaşamakta olup düşük düzeyde problem çözme becerisine sahiptirler. Öğrenciler sınav sırasında aceleci ve düşünen bir yaklaşımla problem çözme davranışı gösterdiklerinde ilgisiz boyutta bir sınav kaygısı yaşayabilirler.
\end{abstract}

Anahtar Kelimeler: Beceri sınavı, Hemşirelik öğrencileri, Problem çözme becerisi, Sınav kaygısı.

\begin{abstract}
Aim: The study was conducted with the aim of investigating the levels of and relations between problem solving skills and test anxiety of first year nursing students during skill practice exam.

Method: Sample of the descriptive and correlational research consisted of first year nursing students at the nursing department of a university's Faculty of Health Sciences $(n=68)$. Revised Test Anxiety Scale and Problem Solving Inventory were used for data collection. Data of the research was collected in 2018.

Results: Students' test anxiety total average score was detected as 41.04 \pm 9.60 (Min.=24-Max.=66) and problem solving total average score was detected as 87.82 \pm 17.15 (Min.=46-Max.=127). Statistically significant relationships were detected between Precipitant Approach, Thinking Approach dimension scores and total scores of Problem Solving Inventory and Exam Irrelevant Thoughts dimension of Revised Test Anxiety Scale $(p<0.05)$. Furthermore, it was identified that the worry subscale level of test anxiety of male students were statistically higher than female students and they are more hasty in problem solving $(\mathrm{p}<0.05)$.

Conclusion: Nursing first year students experience a moderate level of test anxiety during the skill practice exam and have a low level of problem solving skills. Students may experience an unrelated subscale of test anxiety when they show problem solving behavior in a hasty and thinking manner during the exam.
\end{abstract}

Keywords: Skill exam, Nursing students, Problem solving skill, Test anxiety.

\section{Giriş}

Kayg1, psikolojide insanoğlunun yaşadığ durumu ifade eder ve insanların kendi düşünceleri

sonucu ortaya çıkar [1]. Kaygı durumluk ve sürekli olmak üzere iki şekilde ele alınmaktadır. Bireyin içinde 
bulunduğu stresli durumdan dolayı hissettiği subjektif korkudur. Sürekli kaygı ise zararsız olan durumları bireyin tehlikeli ve özünü tehdit edici algılaması nedeniyle oluşan hoşnutsuzluk ve mutsuzluk duygusu olarak tanımlanmaktadır [2]. Özel bir kaygı türü olarak belirtilen sınav kaygısı, değerlendirme, sınav ya da başarısızlığın söz konusu olabileceği durumlarda ortaya çıkan, bireyin performansını olumsuz yönde etkileyen; bilişsel, duyuşsal ve davranışsal belirtilerle kendini gösteren durumdur [3].

Hemşirelik eğitimi, teorik bilgi ve el becerileri kazanmayı; gözlem ve kritik karar verebilmeyi gerektiren; teorik ve pratik eğitim ve öğretimi kapsayan bir süreçtir. $\mathrm{Bu}$ sürecin sonunda hemşirelik öğrencilerinden bilgi, beceri, tutum ve bilimsel problem çözme yöntemlerini kullanarak hastaların sağlı sorunlarını gidermeleri beklenir [4]. Bu beklentileri gidermeyi öğrenmeye çalışan öğrenci klinik ortamda ya da okuldaki laboratuvar çalışmaları sırasında olumlu deneyimlerin yanı sıra birtakım olumsuz deneyimler de yaşayabilir. $\mathrm{Bu}$ olumsuz deneyimler sonucu ortaya çıkabilen kaygı ya da stres hemşirelik öğrencileri arasında evrensel bir sorun olarak karşımıza çıkmaktadır [4,5]. Aynı zamanda hemşirelik öğrencileri eğitimleri boyunca birçok sınavdan geçmektedir. Bu sinavlarda fiziksel belirtilere yol açabilen; çapında en önemli eğitim sorunlarından biri olarak görülen; öğrencinin akademik başarısını ve problem çözebilme yeteneğini etkileyebilen sınav kaygısını hemşirelik öğrencileri de yoğun bir şekilde deneyimlemektedir [6].

Hemşirelik öğrencilerinin, yazılı ya da sözlü sınavlarda, beceri uygulama sınavlarında, sosyal hayatlarında ya da her ne sebeple olsun yaşadıkları kaygı ve stresle baş edebilmeleri için, etkili problem çözme becerilerini öğrenmeleri ve yaşadıkları bu sınav kaygısını uygun problem çözme teknikleri ile baş edebilmeyi öğrenmeleri gerekmektedir.

Problem çözme; ulaşılmak istenen amaca yönelik en uygun çözüm yollarının saptanması şeklinde tanımlanmaktadır [7]. Problem çözme becerisi yüksek kişilerin yenilikçi, değişime açık, eleştirel bakış açısına sahip [8,9], esnek ve yaratıcı kişiler oldukları ve bu niteliklere sahip bireylerin aynı zamanda profesyonel bir hemşirede aranan mesleki özelliklerden biri olduğu vurgulanmaktadır [10]. Hemşire, birey ile toplumun durumu farklılaştıkça; değişimi algılar, görüş bildirir ve yeni bilgileri bir araya toplayarak, problem çözme aşamalarını pratiğe yansıtır [11]. Hemşirelik meslek üyeleri ne kadar yeterli seviyede problem çözme becerisine sahip olursa o derecede bireyin ve toplumun sağlığını koruma, geliştirme ve yaşam doyumunu artırma bağlamında etkili hizmet sunabilirler [12-15].

Literatürde problem çözme becerisine ilişkin; sağlık profesyonelleri, hemşireler, hemşirelik öğrencileri ve sağlık yüksekokulu öğrencileri ile yapılmış çalışmalar olmasına rağmen [8-16], beceri uygulama sınavi sırasındaki kaygı ile problem çözme becerisi arasındaki ilişkiyi inceleyen çalışmalara rastlanamadı. Bu sebeple bu çalışmada hemşirelik birinci sınıf öğrencilerinde beceri uygulama sınavı sırasındaki sınav kaygısı ve problem çözme becerisi arasındaki ilişkinin belirlenmesi amaçlanarak şu sorulara yanıtlar arand1:

Hemşirelik birinci sınıf öğrencilerinin beceri uygulama sınavındaki sınav kaygı düzeyleri ve problem çözme beceri düzeyleri nedir?

Hemşirelik birinci sınıf öğrencilerinin beceri uygulama sınavında sınav kaygı düzeyleri ile problem çözme beceri düzeyleri arasında ilişki var mıdır?

Hemşirelik birinci sınıf öğrencilerinin cinsiyetlerine göre beceri uygulama sınavındaki sınav kayg1 düzeyleri ve problem çözme beceri düzeyleri arasında farklılık var midır?

\section{Gereç ve Yöntem}

Tanımlayıcı ve ilişki arayıcı tipteki araştırma, bir üniversitenin Sağlık Bilimleri Fakültesi hemşirelik birinci sınıf öğrencilerinin beceri uygulama sınavı sırasındaki sınav kaygısı ve problem çözme beceri düzeyleri ile bunların arasındaki ilişkiyi belirlemek amacıyla gerçekleştirildi.

\subsection{Araştırmanın Evreni ve Örneklemi}

Araştırmanın evrenini 2017-2018 eğitim-öğretim yılında Hemşirelik Esasları dersini alan Sağlık Bilimleri Fakültesi hemşirelik bölümü birinci sınıf öğrencileri $(\mathrm{N}=72)$ oluşturdu. Öğrencilerin sınav kaygıları ve problem çözme davranışları sürekli değişkenler olarak ölçüldü. Buna göre, \%95 (1- $\alpha)$ güven aralığında $(\mathrm{t}=1,96)$, standart sapma (S) 0,5 olarak tahmin edildiğinde ve \% 5 (d) hata oranı ile evreni bilinen örneklem büyüklüğü ile [17]; $n=n_{0} /\left(1+n_{0} / N\right)$ ve $\mathrm{n}_{\mathrm{o}}=(\mathrm{tS} / \mathrm{d})^{2}$ formüllerinde; $\mathrm{N}$ : Evren büyüklüğü, $\mathrm{t}$ : Güven düzeyine karşılık gelen tablo değeri, d: sapma miktarı, tolere edilmek istenen aralık genişliği, $\mathrm{n}_{0}$ : örneklem büyüklüğü için en iyi tahmin, $\mathrm{S}$ : Evren için tahmin edilen standart sapmayı gösterir. $\mathrm{Bu}$ formüller kullanılarak örneklem büyüklüğü yaklaşık 61 kişi olarak hesaplandı. Çalışmaya katılmaya isteklilik ve gönüllülük ilkesi, Hemşirelik Esasları dersini ilk kez alma ve Hemşirelik Esasları dersinin uygulama beceri sınavına katılma araştırmaya dahil edilme kriterlerini oluşturdu. Uygulama beceri sınavının yapıldığı gün okula gelmeyen ve sinava katılmayan $(n=4)$ öğrenciler araştırma dışında bırakıldı. Uygulama beceri sınavına katılan, araştırmaya katılmaya istekli ve gönüllü olan 68 öğrenci ile araştırma tamamlandı. Örneklem büyüklüğünün yapılan örneklem hesabına göre genellenebilirlik açısından yeterli olduğu söylenebilir.

\subsection{Veri Toplama Araçları}

Araştırmanın verileri "Öğrenci Bilgi Formu", "Revize Edilmiş Sınav Kaygısı Ölçeği" ve "Problem Çözme Becerileri Envanteri” ile topland. Öğrenci Bilgi Formunda; örneklem grubunu oluşturan öğrenciler aynı yaş grubunda ve sınıfta oldukları için öğrencilerin sosyo-demografik bilgilerinden sadece cinsiyet sorgulandi. 
2.2.1. Revize Edilmiş Sınav Kaygısı Ölçeği (RESKÖ): İlk olarak 1980 yılında Spielberger tarafından geliştirilen Sınav Kaygı Envanteri, 1984 yılında Sarason tarafindan revize edilmiştir. Daha sonra 1992 yılında Benson ve ark.'nın yaptıkları çalışmalar sonucunda "gerginlik, bedensel belirtiler, endişe ve sınavlarla ilgisiz düşünceler" olmak üzere sınav kaygısını dört boyutla ölçen Revize Edilmiş Sınav Kaygısı Ölçeği geliştirilmiştir. Benson ve El-Zahhar de 1994'de ölçeğin geçerlik ve güvenirlik analizleri için kültürler arası bir çalışma yaparak ölçeğe son halini vermişlerdir. Ölçeğin Türkçe'ye uyarlaması 2012 yılında Akın ve ark. tarafından yapılmıştır [3]. Sınav sırasında öğrencilerin yaşadığı sınav kaygısının boyutlarını incelemek ve sinav kaygısının hangi yapılarla birlikte ortaya çıktığını tespit etmek amacıyla ölçeğin kullanılması önerilmektedir. Daha önce psikomotor beceri sınavında kullanıldığı çalışmalara rastlanmayan ölçek, "Gerginlik (4, 5, 6, 12, 20. maddeler)", "Bedensel Belirtiler (10, 15, 16, 17, 18. maddeler)", "Endişe (1, 2, 3, 8, 11, 19. maddeler)" ve "Sınavla İlgisiz Düşünceler (7, 9, 13, 14. maddeler)" olmak üzere dört alt boyuttan ve toplam 20 maddeden oluşmaktadır. Dörtlü likert tipindeki ölçek, Hiçbir zaman (1), Bazen (2), Çoğu zaman (3), Her zaman (4) şeklinde puanlandırılmaktadır. Ölçekten alınabilecek en düşük puan 20 sınav kaygısının düşük olduğunu, 80 puan ise sınav kaygısının çok yüksek olduğunu göstermektedir. Ölçek hem alt boyutlara göre hem de toplam bir sınav kaygısı puanı vermektedir. Ölçeğin orijinalindeki Cronbach Alfa değeri 0,84'dür [3], bu çalışmadaki Cronbach Alfa değeri 0,89'dur.

2.2.2. Problem Çözme Becerileri Envanteri (PÇBE): 1982 yilinda Heppner ve Peterson [18] tarafindan geliştirilen envanterin Türkçe uyarlaması Şahin, Şahin ve Heppner tarafından 1993 yılında yapılmıştır [19]. Ergen ve yetişkinlerin problem çözme becerisi konusunda kendi algılayışını ölçen olumlu ve olumsuz ifadelerin yer aldığ 35 maddeden oluşan ve 1-6 arası puanlanan likert tipi bir ölçektir. Her madde için kişilere kendilerinin hangi sıklıkla ölçek maddelerindeki gibi davrandıkları sorulmaktadır. Seçenekler: "Her zaman böyle davranırım=1", "Çoğunlukla böyle davranırım=2", "Sık sık böyle davranırım=3", "Arada sırada böyle davranırım=4", "Ender olarak böyle davranırım $=5$ " ve "Hiçbir zaman böyle davranmam=6" şeklindedir. Puanlama esnasında 9, 22 ve 29. maddeler puanlama diş1 tutulur. 1, 2, 3, 4, 11, 13, 14, 15, 17, 21, $25,26,30$ ve 34 . maddeler ters olarak puanlanan maddelerdir. Ölçekten alınan toplam puanların yüksekliği, bireyin problem çözme becerileri konusunda kendini yetersiz olarak algıladığını gösterir. Ölçekten alınabilecek en düşük puan 32 , en yüksek puan ise 192'dir. Ölçekten alınan puanların yüksekliği, bireyin problem çözme becerileri konusunda kendini yetersiz olarak değerlendirdiğini, kaçınma-yaklaşma davranışı gösterdiğini ve kişisel kontrol hissetmediğini göstermektedir. Ölçeğin; "Aceleci yaklaşım (13, 14, 15, $17,21,25,26,30$ ve 32. Maddeler)", "Düşünen yaklaşım (18, 20, 31, 33 ve 35. Maddeler)", "Kaçıngan yaklaşım (1, 2, 3 ve 4. Maddeler)", "Değerlendirici yaklaşım $(6,7$ ve 8 . Maddeler)", "Kendine güvenli yaklaşım $(5,11,23,24,27,28$ ve 34 . Maddeler)" ve "Planlı yaklaşım (10, 12, 16 ve 19. Maddeler)" olmak üzere toplam altı alt boyutu vardır. Ölçeğin orjinalinin Cronbach Alfa tutarlılık katsayısı 0,90, alt ölçekler için elde edilen katsayılar ise, 0,72 ile 0,85 arasındadır $[18,19]$. Çalışmamızdaki Cronbach Alfa değeri 0,791 'dir.

\subsection{Veri Toplama Süreci}

Araştırmanın verileri 2018 güz dönemi eğitim ve öğretim yılının sonunda Hemşirelik Esasları dersi beceri uygulama sınavi sırasında gerçekleştirildi. Beceri uygulama sınavı hemşirelik beceri laboratuvarında, tek bir istasyonda ve dersin sorumlu öğretim elemanı tarafindan yapıldı. Uygulama sinavında; öğrenciler laboratuvara sırayla alınarak, daha önceden hazırlanan ve temel hemşirelik becerilerini içeren uygulama isimlerinin yazıll olduğu torbadan birer beceri ismi çektiler ve bu beceriyi uyguladılar. Revize Edilmiş Sınav Kaygısı Ölçeği ve PÇBE formları, öğrencilerin uygulama sınavındaki akademik başarı puanlarını etkileyebileceği düşünülerek uygulama sınavından sonra uygulandı. Beceri uygulama sınavinın hemen ardından her bir öğrenci laboratuvardan çıkmadan RESKÖ ve PÇBE'yi doldurarak teslim etti.

\subsection{Araştırmanın Etik Yönü}

Araştırma süresince İnsan Hakları Helsinki Deklarasyonu'na sadık kalındı. Araştırma verilerinin toplandığı fakültenin dekanlığına ve üniversitenin rektörlüğüne, çalışmanın amaç ve kapsamını içeren bir bilgi formu ile başvurularak yazılı izin alındı. Ayrıca üniversitenin yerel etik kurul başkanlığından yazılı izin alındı (13/06/2018-E.14738). Örneklemi oluşturan öğrencilere çalışmanın amaç ve yararları, çalışmadaki rolleri açıklandı, veri toplama formlarının üzerine isimlerinin yazılmayacağı söylendi, araştırmaya katılmaya isteklilik ve gönüllülük ilkesine özen gösterilerek sözel olarak izinleri alındı.

\subsection{Verilerin Analizi}

$\mathrm{Bu}$ çalışmada verilerin çözümlenmesi, incelenmesi ve analizlerin gerçekleştirilmesinde Stastical Package for Social Science for Windows SPSS 23.0 paket programı kullanıldı. Veri analizinde, ordinal değişkenler aritmetik ortalama ve standart sapma, minimum, maksimum olarak değerlendirildi. Ölçeklerin normallik dağılımları Kolmogorov-Simirnov testi; puan dağılımı arasındaki ilişki Pearson Momentler Çarpımı Korelasyon Katsayıs1; öğrencilerin cinsiyet açısından RESKÖ ve PÇBE toplam puanları arasındaki farkların istatistiksel olarak anlamlı olup olmadığı Mann-Whitney U testi ile incelendi. Anlamlılık düzeyi $\mathrm{p}<0,05$ olarak değerlendirildi.

\section{Bulgular}

Çoğunluğunu kız öğrencilerin $\quad(n=52)$ oluşturduğu araş̧ırmada hemşirelik birinci sınıf öğrencilerinin beceri uygulama sınavi sırasindaki RESKÖ'nün alt boyutlarının toplam puan ortalamaları ile toplam puan ortalaması incelendiğinde; RESKÖ'nün “Gerginlik” alt 
boyutu toplam puan ortalamasinin 12,61 $\pm 3,29$ (Min.=6Mak.=20); "Bedensel belirtiler" alt boyutu toplam puan ortalamasının 9,41 $\pm 3,85$ (Min.=5-Mak.=27); "Endişe" alt boyutu toplam puan ortalamasinın 12,52 $\pm 2,94$ (Min.=6-Mak.=21); "Sınavla ilgisiz düşünceler" alt boyutu toplam puan ortalamasinın 6,54 $\pm 2,58$ (Min.=4Mak.=15) ve RESKÖ'nün toplam puan ortalamasının 41,04 $\pm 9,60 \quad($ Min.=24-Mak.=66) olduğu belirlendi (Tablo 1).

Tablo 1. Öğrencilerin Beceri Uygulama Sınavı Sırasındaki Sınav Kaygısı Ölçeği ve Problem Çözme Becerileri Envanteri Puan Dağılımları (N=68)

\begin{tabular}{|l|c|c|c|c|c|c|}
\hline Ölçekler & & $\mathbf{N}$ & Minimum & Maksimum & Ortalama & Std. Sapma \\
\hline RESKÖ* $^{*}$ & Gerginlik & 67 & 6 & 20 & 12.61 & 3.29 \\
\hline \multirow{5}{*}{ PÇBE $^{* * *}$} & Bedensel Belirtiler & 68 & 5 & 27 & 9.41 & 3.85 \\
\cline { 2 - 7 } & Endişe Ölçeği & 68 & 6 & 21 & 12.52 & 2.94 \\
\cline { 2 - 7 } & Sinavla ilgisiz Düşünceler & 68 & 4 & 15 & 6.54 & 2.58 \\
\cline { 2 - 7 } & Toplam & $\mathbf{6 8}$ & $\mathbf{2 4}$ & $\mathbf{6 6}$ & $\mathbf{4 1 . 0 4}$ & $\mathbf{9 . 6 0}$ \\
\cline { 2 - 7 } & Aceleci Yaklaşım & 67 & 18 & 44 & 29.84 & 5.52 \\
\cline { 2 - 7 } & Düşünen Yaklaşım & 68 & 5 & 28 & 12.91 & 4.21 \\
\cline { 2 - 7 } & Keçıngan Yaklaşım & 66 & 4 & 19 & 9.64 & 3.74 \\
\cline { 2 - 7 } & Kendindendirici Yaklaşım & 68 & 3 & 18 & 7.72 & 2.82 \\
\cline { 2 - 7 } & Planli Yaklaşım & 67 & 4 & 35 & 18.13 & 5.23 \\
\cline { 2 - 7 } & Toplam & $\mathbf{6 8}$ & $\mathbf{4 6}$ & $\mathbf{1 2 7}$ & $\mathbf{8 7 . 8 2}$ & $\mathbf{1 7 . 1 5}$ \\
\hline
\end{tabular}

*Revize Edilmiş Sınav Kaygısı Ölçeği

**Problem Çözme Becerileri Envanteri

Hemşirelik birinci sınıf öğrencilerinin beceri uygulama sınavı sırasındaki PÇBE'nin alt boyutlarının toplam puan ortalamaları ile toplam puan ortalaması incelendiğinde; PÇBE'nin “Aceleci yaklaşım" alt boyutu toplam puan ortalamasının 29,84 $\pm 5,52$ (Min.=18-Mak.=44); "Düşünen yaklaşım" alt boyutu toplam puan ortalamasinin 12,91 $\pm 4,21 \quad$ (Min.=5Mak.=28); "Kaçıngan yaklaşım" alt boyutu toplam puan ortalamasının $9,64 \pm 3,74 \quad$ (Min.=4-Mak.=19); "Değerlendirici yaklaşım" alt boyutu toplam puan ortalamasının 7,72 $\pm 2,82$ (Min.=3-Mak.=18); "Kendine güvenli yaklaşım" alt boyutu toplam puan ortalamasının 18,13 $\pm 5,23$ (Min.=7-Mak.=35); "Planlı yaklaşım" alt boyutu toplam puan ortalamasinın 9,64 $\pm 3,32$ (Min. $=4$ Mak.=20) ve PÇBE toplam puan ortalamasının $87,82 \pm 17,15$ (Min.=46-Mak.=127) olduğu saptand 1 (Tablo 1).

Öğrencilerin beceri uygulama sınavı sırasındaki sınav kaygı durumları ile problem çözme becerileri arasındaki ilişki incelendiğinde; PÇBE'nin toplam puan ortalaması, PÇBE'nin "Aceleci yaklaşım" ve "Düşünen yaklaşım" alt boyutları ile RESKÖ’nün "Sinavla ilgisiz düşünceler" alt boyutu arasında sırasıyla istatistiksel olarak pozitif yönlü anlamlı zayıf bir ilişki olduğu belirlendi ( $r=0,338, p<0,01 ; r=0,323, p<0,01 ; r=0,270$, $\mathrm{p}<0,05$ ) (Tablo 2). PÇBE ve RESKÖ'nün toplam puan ortalamaları arasında istatistiksel olarak anlamlı bir ilişki olmadığı görüldü ( $\mathrm{p}>0,05)$ (Tablo 2).

Öğrencilerin cinsiyet açısından RESKÖ ile PÇBE toplam puan ve alt boyut puan ortalamaları karşılaştırıldığında; erkek öğrencilerin PÇBE’nin "Aceleci yaklaşım" alt boyut puan ortalamasının $(32,53 \pm 5,04) \mathrm{k1z}$ öğrencilerin puan ortalamasından $(29,01 \pm 5,57)$ istatistiksel anlamlılıkla yüksek olduğu $(p<0,05)$; yine erkek öğrencilerin RESKÖ’nün "Endişe"

alt boyut puan ortalamasinın $(14,46 \pm 3,07) \quad \mathrm{k} 1 \mathrm{z}$ öğrencilerin puan ortalamasından $(12,11 \pm 2,77)$ istatistiksel olarak anlamlı derecede yüksek olduğu $(\mathrm{p}<0,05)$; PÇBE ve RESKÖ toplam puan ortalamaları arasında ise istatistiksel olarak anlamlı bir farklılık olmadığ1 görüldü ( $\mathrm{p}>0,05)$ (Tablo 3).

\section{Tartışma}

Hemşirelik eğitimi, hem bilişsel ve duyuşsal hem de psikomotor alanlardaki eğitimi içerdiğinden [20] çoğunlukla maketler üzerinde uygulama/pratik yapmayı gerektirir. $\mathrm{Bu}$ eğitim sayesinde öğrencilerin gerçek klinik ortamda hazır oluşları sağlanır [21]. Diğer bir ifadeyle öğrenciler bedensel, duygusal ve zihinsel değişimlerle kendini gösteren aşırı uyarılmışlık durumunu kontrol edebilmeyi ve etkin problem çözebilmeyi öğrenebilirler [16]. Bu çalışmada hemşirelik birinci sınıf öğrencilerinin beceri uygulama sınavı sırasındaki sınav kaygısı ile problem çözme becerisi arasındaki ilişkinin belirlenmesi amaçlandı.

Problem çözme, hemşirelik öğrencilerinin eğitimleri sırasında geliştirmeleri gereken temel bir yetenektir [15]. Bu nedenle hemşirelik öğrencilerinin problem çözme yeteneklerinin ve bunu etkileyen faktörlerin araştırılmasına gereksinim vardır. $\mathrm{Bu}$ çalışmada, hemşirelik birinci sınıf öğrencilerinin hemşirelikte temel ilkeler dersine yönelik yapılan beceri uygulama sınavı sırasındaki problem çözme beceri düzeyleri incelendiğinde; hemşirelik öğrencilerinin PÇBE toplam puan ortalamasının $87,82 \pm 17,15$ olduğu saptandı ve bu değer orta düzeyde değerlendirilebilir. Ölçeğin toplamından elde edilecek toplam puan aralığ 32 192'dir. Problem Çözme Becerileri Envanteri'nden elde edilen toplam puanın yüksek olması, bireyin problem çözme becerileri konusunda kendini yeterli olarak algıladıklarını göstermektedir. 
Tablo 2. Öğrencilerin Beceri Uygulama Sınavı Sırasındaki Sınav Kaygısı Ölçeği ve Problem Çözme Becerileri Envanteri Arasındaki İlișki

\begin{tabular}{|c|c|c|c|c|c|c|c|}
\hline & & & \multicolumn{5}{|c|}{ Sinav Kaygısı Alt Boyutları } \\
\hline & & & \begin{tabular}{|c|} 
Sinav Kaygis1 \\
Toplam
\end{tabular} & \multirow{2}{*}{\begin{tabular}{|c|} 
Gerginlik \\
-.032
\end{tabular}} & \multirow{2}{*}{$\begin{array}{c}\text { Bedensel } \\
-.047\end{array}$} & \multirow{2}{*}{$\frac{\text { Endişe }}{.176}$} & \multirow{2}{*}{$\frac{\text { İlgisiz }}{.338^{* *}}$} \\
\hline \multirow{3}{*}{\multicolumn{2}{|c|}{$\begin{array}{l}\text { Problem Çözme } \\
\text { Toplam }\end{array}$}} & $\mathrm{r}$ & .115 & & & & \\
\hline & & $p$ & .351 & .795 & .702 & .152 & .005 \\
\hline & & $\mathrm{N}$ & 68 & 67 & 68 & 68 & 68 \\
\hline \multirow{3}{*}{\multicolumn{2}{|c|}{ Aceleci }} & $\mathrm{r}$ & .084 & -.031 & -.087 & .127 & $.323^{* *}$ \\
\hline & & $p$ & .500 & .803 & .484 & .305 & .008 \\
\hline & & $\mathrm{N}$ & 67 & 66 & 67 & 67 & 67 \\
\hline & \multirow[t]{3}{*}{ Düşünen } & $\mathrm{r}$ & .119 & .021 & -.023 & .158 & $.270^{*}$ \\
\hline & & $p$ & .333 & .864 & .855 & .197 & .026 \\
\hline & & $\mathrm{N}$ & 68 & 67 & 68 & 68 & 68 \\
\hline \multirow{6}{*}{${ }^{2}$} & \multirow{3}{*}{ Kaçıngan } & $\mathrm{r}$ & .040 & -.047 & -.069 & .114 & .182 \\
\hline & & $p$ & .750 & .712 & .583 & .363 & .143 \\
\hline & & $\mathrm{N}$ & 66 & 65 & 66 & 66 & 66 \\
\hline & \multirow{3}{*}{ Değerlendirici } & $\mathrm{r}$ & .064 & -.005 & -.004 & .088 & .165 \\
\hline & & $p$ & .602 & .967 & .972 & .477 & .180 \\
\hline & & $\mathrm{N}$ & 68 & 67 & 68 & 68 & 68 \\
\hline \multirow{3}{*}{ ב. } & \multirow[t]{3}{*}{ Kendine güvenli } & $\mathrm{r}$ & .081 & -.078 & .002 & .159 & .217 \\
\hline & & $p$ & .510 & .530 & .984 & .197 & .076 \\
\hline & & $\mathrm{N}$ & 68 & 67 & 68 & 68 & 68 \\
\hline छ & \multirow{3}{*}{ Planlı } & $\mathrm{r}$ & .103 & .033 & .025 & .070 & .228 \\
\hline$\overline{0}$ & & $p$ & .405 & .793 & .844 & .572 & .063 \\
\hline \pm & & $\mathrm{N}$ & 67 & 66 & 67 & 67 & 67 \\
\hline
\end{tabular}

Literatürde hemșirelik birinci sınıf öğrencilerinin beceri uygulama sınavı sırasındaki problem çözme becerilerinin incelendiği çalışmalara rastlanmamakla birlikte, hemşirelik öğrencilerinin problem çözme becerilerinin değişik șekillerde incelendiği araştırmalar bulunmaktadır. Çalışmaya benzer şekilde hemşirelik öğrencilerinin PÇBE toplam puan ortalamasının Tezel

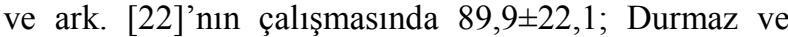
ark. [23]'nın çalışmasında 88,28 20,42 ; Şahiner ve ark. [24]'nın çalışmasında 82,82 $\pm 15,93$; Yurttaş ve Yetkin [11]'in çalı̧̧masında $80,25 \pm 17,00$ olduğu ifade edilmektedir. Öte yandan Kanbay ve ark. [10]'nın çalışmasında hemşirelik birinci sınıf öğrencilerinin PÇBE toplam puan ortalamasının $92,867 \pm 2,41$; Erol ve ark. [16]'nın çalışmasında 97,33 $\pm 14,76$ şeklinde ve orta düzeyde olduğu belirtilerek çalışmamıza benzerlik göstermemektedir. $\mathrm{Bu}$ sonuçlar yaş, cinsiyet, kültür, deneyim, aile yapısı ve yaşadığı çevre ile ilişkilendirilebilir. Problem çözmeyi bilmek demek her zaman her karşılaşılan zorlukların üstesinden gelinebileceği anlamı taşımayabilir. Bir sorunun çözümlenebilmesinde problem çözme becerilerinin yüksek olması kadar bireyin karşılaştığı sorunu kendi sorumluluk alanı içinde görmesi de önemlidir $[11,23]$. Öte yandan Mete ve Uysal hemşirelik öğrencilerinden aldıkları geri bildirimlere göre öğrencilerin laboratuvar ortamında kritik düşünme ve problem çözme becerilerini kullanamadıklarını; laboratuvar ortamında fazla zaman geçirmekten sıkıldıklarını ifade etmektedirler [21]. Bu nedenle aynı öğrenci grubunun farklı değişkenler açısından problem çözme becerilerinin incelenmesi, farklı eğitim modeli olan okullarla sonuçların karşılaştırılması önerilebilir.

Çalışmada hemşirelik birinci sınıf öğrencilerinin beceri uygulama sınavı sırasında orta düzeyde sınav kaygısı yaşadıkları belirlendi. Sağkal Midilli ve ark.'nin çalışmasında, hemşirelik öğrencilerinin kaygı düzeyinin $(49,73 \pm 1,27)$ orta düzeyde olduğunu ifade edilmektedir [25]. Bu sonuç çalıșma bulgumuzla benzerdir. Hemşirelik eğitiminde teorik bilgiler yazılı sınavlarla değerlendirilebilirken öğrencilerin beceri, tutum ve davranışları beceri uygulama sınavları ile değerlendirilmektedir. Beceri sınavlarının uygulanma şekli okullara ve öğretim elemanlarına göre farklılık göstermekle birlikte belli bir standart bulunmamaktadır [26]. Bu anlamda beceri uygulama laboratuvarlarının ve uygulama şekillerinin değerlendirildiği çalışmalara gereksinim olabilir. Laboratuvar uygulama ortamları, beceri sınavlarının yöntemleri hemşirelik öğrencilerinin o anki sınav kaygısını etkilemiş olabileceği düşünülmektedir. Tel ve ark., hemşirelik birinci sınıf öğrencilerinin laboratuvar ortamında beceri uygulamaları sırasında hafifle orta düzeyde değişen anksiyete yaşadıklarını vurgulamaktadırlar [27]. Çalışmada, öğrencilerin problemi aceleci ve düşünen bir yaklaşım ile çözdüklerinde sınavla ilgisiz olarak sınav kaygısı yaşadıkları; problem çözme beceri düzeyleri azaldığında yüksek düzeyde sınavla ilgisiz düşüncelere kapılarak sınav kaygılarının arttığı bulundu. 
Tablo 3. Öğrencilerin Cinsiyet Açısından Problem Çözme Becerileri Envanteri ve Sınav Kaygısı Ölçeği’nin Alt Boyutları İle Toplam Puan Ortalamalarının Karşılaștırılması

\begin{tabular}{|c|c|c|c|c|c|c|}
\hline Alt & Cinsiyet & $\mathbf{N}$ & Ort. & SD & $\mathbf{Z}$ & $\mathbf{p}^{\mathbf{a}}$ \\
\hline \multirow{2}{*}{ PÇBE Aceleci } & Kadın & 51 & 29.01 & 5.57 & \multirow{2}{*}{-1.991} & \multirow{2}{*}{.046} \\
\hline & Erkek & 13 & 32.53 & 5.043 & & \\
\hline \multirow{2}{*}{ PÇBE Düşünen } & Kadın & 52 & 12.88 & 4.29 & \multirow{2}{*}{-.033} & \multirow{2}{*}{.974} \\
\hline & Erkek & 13 & 13.00 & 4.26 & & \\
\hline \multirow{2}{*}{ PÇBE Kaçıngan } & Kadın & 50 & 9.44 & 3.70 & \multirow{2}{*}{-.922} & \multirow{2}{*}{.357} \\
\hline & Erkek & 13 & 10.69 & 4.21 & & \\
\hline \multirow{2}{*}{ PÇBE Değerlendirici } & Kadın & 52 & 7.75 & 2.95 & \multirow{2}{*}{-.621} & \multirow{2}{*}{.535} \\
\hline & Erkek & 13 & 8.00 & 2.51 & & \\
\hline \multirow{2}{*}{\begin{tabular}{|l|} 
PÇBE \\
Kendine güvenli
\end{tabular}} & Kadın & 52 & 18.01 & 5.571 & \multirow[b]{2}{*}{-.715} & \multirow[b]{2}{*}{.475} \\
\hline & Erkek & 13 & 18.92 & 4.34 & & \\
\hline \multirow{2}{*}{ PÇBE Planlı } & Kadın & 51 & 9.49 & 3.34 & \multirow{2}{*}{-.957} & \multirow{2}{*}{.339} \\
\hline & Erkek & 13 & 10.46 & 3.33 & & \\
\hline \multirow{2}{*}{ PÇBE* } & Kadın & 52 & 86.56 & 18.17 & \multirow{2}{*}{-1.567} & \multirow{2}{*}{.117} \\
\hline & Erkek & 13 & 93.62 & 13.54 & & \\
\hline \multirow{2}{*}{ RESKÖ Gerginlik } & Kadın & 51 & 12.6863 & 3.48419 & \multirow{2}{*}{-.310} & \multirow{2}{*}{.756} \\
\hline & Erkek & 13 & 12.2308 & 2.61896 & & \\
\hline \multirow{2}{*}{ RESKÖ Bedensel } & Kadın & 52 & 9.4231 & 4.04071 & \multirow{2}{*}{-.216} & \multirow{2}{*}{.829} \\
\hline & Erkek & 13 & 9.0769 & 3.14806 & & \\
\hline \multirow{2}{*}{ RESKÖ Endişe } & Kadın & 52 & 12.1154 & 2.77703 & \multirow{2}{*}{-2.294} & \multirow{2}{*}{.022} \\
\hline & Erkek & 13 & 14.4615 & 3.07179 & & \\
\hline \multirow{2}{*}{ RESKÖ İlgisiz } & Kadın & 52 & 6.1346 & 2.15141 & \multirow{2}{*}{-1.792} & \multirow{2}{*}{.073} \\
\hline & Erkek & 13 & 7.8462 & 3.50823 & & \\
\hline RFSKÖ** & Kadın & 52 & 40.31 & 9.45 & -0.821 & 412 \\
\hline & Erkek & 13 & 43.62 & 10.91 & -0.021 & \\
\hline
\end{tabular}

Karmaşık bir süreç olan problem çözme bilişsel, duyuşsal ve davranışsal etkinlikleri içermektedir. Aynı zamanda problem çözme öğrenilebilen ve birtakım yaşantılarla geliştirilebilen bir yetenektir [28]. Hemşirelik öğrencilerinin beceri uygulama sınavı sırasındaki sınav kaygısı ve problem çözme becerilerini etkileyebilecek birçok faktör olabilir. Ancak bu araștırmada bu faktörler incelenmedi. Sağkal Midilli ve ark.'nın hemşirelik öğrencilerinin laboratuvar uygulamalarındaki bilgi ve becerileri ile sınav kaygısının ilişkini inceledikleri çalışmada; öğrencilerin bazı hemşirelik temel becerilerde bilgi ve beceri düzeylerinin yüksek olduğu ve bu beceri puanları ile sınav kaygısı arasında bir ilişki olmadığ bildirilmektedir [25]. Literatürde öğrencilerin sinav kaygısı ile akademik başarı puanları arasındaki ilişkinin incelendiği çalışmalarda öğrencilerin düşük düzeyde sınav kaygısı yaşadıkları [29] ve sınav kaygısı ile akademik başarı ya da bilgi ve beceri düzeyleri arasında anlamlı bir ilişki olduğu; sınav kaygısı düştükçe akademik başarı puanlarının yükseldiği belirtilmektedir [30]. Ayrıca beceri uygulama sınavindaki sınav kaygısı ile problem çözme becerisi arasındaki doğrudan ilişkiyi veya bunu etkileyen faktörleri inceleyen çalışmalara rastlanamadı. Sınav kaygısını yenmede problem çözme becerisinin geliştirilmesi için cinsiyet, yaş, yaşla artan deneyim, eğitim gibi faktörlerin önemli olduğu söylenebilir.
Çalışmada beceri sınavında hemşirelik öğrencilerinin cinsiyete göre problem çözme beceri düzeyleri ile sınav kaygı durumları karşılaştırıldığında; erkek öğrencilerin aceleci yaklaşım alt boyutunda problem çözme beceri düzeylerinin $\mathrm{k} 1 \mathrm{z}$ öğrencilere oranla düşük düzeyde olduğu; yine erkek öğrencilerin endişe alt boyutunda kız öğrencilere oranla daha fazla sınav kaygısı yaşadıkları bulundu. Olgun ve ark.'nın yaptığı çalışmada hemşirelik birinci sınıf öğrencilerinde cinsiyet açısından problem çözme beceri düzeylerinde anlamlı farklılık olmadığ 1 [31]; Koç ve ark.'nın çalışmasında ise erkek öğrencilerin problem çözme becerilerinin diğer öğrencilerden daha yüksek olduğu belirtilmektedir [32]. Çalışmada erkek öğrencilerin sayısının kız ögrencilerden az olmasından dolayı bu sonuca varıldığ düşünülmektedir.

Öte yandan farklı ve benzer öğrenci gruplarında kız öğrencilerin erkek öğrencilerden daha fazla sinav kaygısı yaşadıkları bildirilmektedir [7,25].

Çalışmada erkek öğrencilerin aceleci yaklaşım boyutunda problem çözme beceri düzeylerinin kızlara göre düşük düzeyde olması beceri uygulama sınavında endişe boyutunda daha fazla sınav kaygısı yaşamalarına neden olduğunu düşündürmektedir. Ancak erkek ve kız öğrencilerin sayılarının daha homojen olduğu öğrenci grupları ile çalışmanın tekrar edilmesi önerilebilir. 


\section{Sinırlılıkları}

Araştırma sonuçlarının sadece örneklem grubuna genellenebilmesi, araştırmada her bir öğrencinin farklı bir beceriyi uygulamasından dolayı öğrencilerin beceri puanları ile RESKÖ ve PÇBE'nin karşılaştırılamaması araştırmanın sınırlılıklarını oluşturmaktadır. Çalışmada öğrencilerin sınav performansını ve akademik başarı puanlarını etkilememek için RESKÖ uygulama sınavının hemen ardından uygulandı. Bu ölçme yöntemi de araştırmanın diğer bir sınırlılığını oluşturmaktadır ve bu nedenle öğrencilerin sinav kaygı düzeyinin orta düzeyde ölçülmüş olabileceği düşünülmektedir.

\section{Sonuç ve Öneriler}

Çalışmada, hemşirelik birinci sınıf öğrencilerinin beceri uygulama sinavı sirasında orta düzeyde sınav kaygısı yaşadıkları; problem çözme beceri düzeylerinin düşük olduğu belirlendi. Öğrencilerin aceleci ve düşünen yaklaşım boyutundaki problem çözme davranışları ile ilgisiz boyuttaki sınav kaygı düzeyleri ile pozitif yönlü ve zayıf ilişkilidir. Erkek öğrencilerin aceleci yaklaşım boyutunda problem çözme beceri düzeyinin daha düşük olduğu ve endişe boyutunda kızlardan daha yüksek düzeyde sınav kaygısı yaşadıkları bulundu. Sınav kaygısı dünya çapında eğitim sürecinin önemli bir sorunudur. Öte yandan problem çözme becerisi hemşirelik uygulamalarının temelini oluşturmaktadır. Dolayısıyla hemşirelik eğitiminde daha ilk yıllarda bu becerinin öğrencilere kazandırılmasına yönelik düzenlemeler ve rehberler oluşturulmalı, öğrencilerin problem çözme beceri düzeyleri her sınıfta ölçülmelidir. Ayrıca özellikle uygulama sınavlarında hemşirelik öğrencilerinin sınav kaygı düzeyleri ve problem çözme becerileri, yaş, eğitim düzeyi, ailenin eğitim düzeyi, akademik başarı puanı gibi farklı değişkenler açısından da değerlendirilebilir.

\section{Kaynaklar}

1. Manav F. Kaygı kavramı. Toplum Bilimleri Dergisi, 2011, 5(9), 201-211.

2. Sanlı Kula K, Saraç T. Fen edebiyat fakültesi öğrencilerinin kayg1 ve umutsuzluklarının incelenmesi, Çukurova Üniversitesi Sosyal Bilimler Enstitüsü Dergisi, 2017, 26(2), 14-29.

3. Akın A, Demirci İ, Arslan S. Revize Edilmiş Sınav Kaygısı Ölçeği: Geçerlik ve güvenirlik çalıșması. Eğitim Bilimleri ve Uygulama, 2012, 11(21), 103-118.

4. Aslan H, Akturk U. Nursing education stress levels of nursing students and the associated factors. Annals of Medical Research, 2018, 25(4), 660-666.

5. Rezaei R, Saatsaz S, Nia HS, Moulookzadeh S, Behedhti Z. Anxiety and critical thinking skills in nursing students. British Journal of Education, Society \& Behavioural Science, 2015, 10(2), 1-7.

6. Sharif F, Dehbozorgi R, Mani Arash, Vossoughi M, Tavakoli P. Theeffect of guided reflection on test anxiety in nursing students. Nursing and Midwifery Studies, 2013, 2(3), 16-20.

7. Kaçan Softa H, Karaahmetoğlu GU, Çabuk F. Lise son sınıf öğrencilerinin sınav kaygısı ve etkileyen faktörlerin incelenmesi. Kastamonu Üniversitesi Kastamonu Eğitim Dergisi, 2014, 23(4), 1481-1494.

8. Applin H, Williams B, Day R, Buro K. A comparison of competencies between problem-based learning and nonproblem-based graduate nurses. Nurse Education Today, 2011 31, 129-134. https://doi.org/10.-1016/j.nedt.2010.05.003.

9. Cooke M, Moyle K. Students' evaluation of problem based learning. Nurse Education Today, 2002, 22(4), 330-339. https://doi.org/10.1054/nedt.2001.0713.

10. Kanbay Y, Aslan Ö, Ișık E, Kılıç N. Hemşirelik lisans öğrencilerinin problem çözme ve eleştirel düşünme becerileri. Yükseköğretim ve Bilim Dergisi, 2013, 3(3), 244-251.

11. Yurttaş A, Yetkin A. Sağlık yüksekokulu öğrencilerinin empatik becerileri ile problem çözme becerilerinin karşılaştırılması. Atatürk Üniversitesi Hemșirelik Yüksekokulu Dergisi, 2003, 6(1), 1-13.

12. Abaan S, Altıntoprak A. Hemşirelerde problem çözme becerileri: öz değerlendirme sonuçlarının analizi. Hacettepe Üniversitesi Hemşirelik Yüksekokulu Dergisi, 2009, 12(1), 62-76.

13. Günüşen NP, Üstün B. Hemşirelik öğrencilerinin problem çözme beceri düzeyleri ile kontrol odağı arasındaki ilişki. Dokuz Eylül Üniversitesi Hemșirelik Yüksekokulu Elektronik Dergisi, 2011, 4(2), 72-77.

14. Kelleci M, Gölbaşı Z. Bir üniversite hastanesinde çalışan hemşirelerin problem çözme becerilerinin bazı değişkenler açısından incelenmesi. Cumhuriyet Üniversitesi Hemşirelik Yüksekokulu Dergisi, 2004, 8(2), 1-8.

15. McEwen M, Brown SC. Conceptual frameworks in undergraduate nursing curricula: report of a national survey. Journal of Nursing Education, 2002, 41(1), 5-14.

16. Erol F, Tanrıkulu F, Dikmen Y, Akduran F. Hemşirelik öğrencilerinin problem çözme becerilerinin bazı değişkenler açısından incelenmesi. Journal of Human Sciences, 2016, 13(3), 5460-5470.

17. Büyüköztürk Ş, Akgün ÖE, Demirel F, Karadeniz Ş, Çakmak EK. Bilimsel Araştırma Yöntemleri. Ankara: Pegem Akademi, 2015.

18. Heppner PP, Petersen CH. The development and implications of a personal problem-solving inventory. , 1982, 29(1), 66-75.

19. Şahin N, Şahin NH, Heppner PP. Psychometric proporties of the Problem Solving Inventory in a group of Turkish University students. Cognitive Therapy and Research, 1993, 17(4), 379-396.

20. Terzioğlu F, Kapucu S, Özdemir L, Boztepe H, Duygulu S, Tuna Z, Akdemir N. Simülasyon yöntemine ilişkin hemşirelik öğrencilerinin görüşleri. Hacettepe Üniversitesi Sağlık Bilimleri Fakültesi Hemşirelik Dergisi, 2012, 19(1), 16- 23.

21. Mete S, Uysal N. Hemşirelik mesleksel beceri laboratuvarındaki psikomotor beceri eğitiminin öğrenci ve eğiticiler tarafindan değerlendirilmesi. Hemşirelikte Araştırma Geliştirme Dergisi, 2010, 2, 28-38.

22. Tezel A, Arslan S, Topal M, Aydoğan Ö, Koç C, Şenlik M. Hemşirelik öğrencilerinin problem çözme becerileri ve depresyon düzeylerinin incelenmesi. Atatürk Üniversitesi Hemşirelik Yüksekokulu Dergisi, 2009, 12(4), 1-10.

23. Durmaz Ş, Kaçar Z, Can S, Koca R, Yeşilova D, Tortumluoğlu G. Canakkale sağllk yüksekokulu ögrencilerinin problem çözme becerileri (PÇB) ve etkileyen bazı faktörler. Atatürk Üniversitesi Hemşirelik Yüksekokulu Dergisi, 2007, 10(4), 63-71.

24. Şahiner G, Açıksöz S, Açıkel C. Hemşirelik yüksekokulu öğrencilerinin problem çözme becerilerinin incelenmesi. Türk Silahlı Kuvvetleri Koruyucu Hekimlik Bülteni, 2013, 12(6), 673-680-688.

25. Sağkal Midilli T, Çevik K, Baysal E. Hemşirelik ögrencilerinin laboratuvar uygulamalarındaki bilgi ve becerileri ile sınav kaygısı iliskisinin incelenmesi. Süleyman Demirel Üniversitesi Sağlık Bilimleri Enstitüsü Dergisi, 2017, $8(1), 43-54$.

26. Boztepe H, Terzioğlu F. Hemşirelik eğitiminde beceri değerlendirme. Anadolu Hemşirelik ve Sağlık Bilimleri Dergisi, 2013, 16(1), 57-64.

27. Tel H, Tel H, Sabancıoğulları S. Hemşirelik birinci sınıf öğrencilerinin laboratuar uygulamasında birbirlerine i.m. enjeksiyon uygularken ve klinik uygulamanın ilk gününde anksiyete durumları. Atatürk Üniversitesi Hemşirelik Yüksekokulu Dergisi, 2004, 7(1), 1-6.

28. Kelleci $M$, Gölbaşı $Z$, Doğan $S$, Tuğut N. Entegre eğitim programında öğrenim gören hemşirelik öğrencilerinin problem çözme becerileri: bir izlem çalışması. İstanbul Üniversitesi Florence Nightingale Hemşirelik Dergisi, 2011, 19(1), 23-28.

29. Kashfi SM, Jeihooni AK, Kashfi SH, Yazdankhah M. The 
relationship between test anxiety and educational performance among the students at school of health and nutrition, Shiraz University of medical sciences in 2011. Journal of Contemporary Medical Education, 2014, 2(3), 158-162.

30. Shakir M. Academic anxiety as a correlate of academic achievement. Journal of Education and Practice, 2014, 5(10), 29-36.

31. Olgun N, Kan Öntürk Z, Karabacak Ü, Eti Aslan F, Serbest Ș Hemşirelik ögrencilerinin problem çözme becerileri: bir yıllık izlem sonuçları. Acıbadem Üniversitesi Sağlık Bilimleri Dergisi, 2010, 1(4), 188-194.

32. Koç Z, Koyuncu S, Sağlam Z. Sağlık yüksekokulu hemşirelik ve ebelik öğrencilerinin problem çözme beceri düzeyleri ve etkileyen faktörler. Hemşirelikte Eğitim ve Araştırma Dergisi, 2015, 12(1), 41-50.

http://edergi.cbu.edu.tr/ojs/index.php/cbusbed

isimli yazarın CBU-SBED başlıklı eseri bu

Creative Commons Alint1-Gayriticari4.0

Uluslararası Lisansı ile lisanslanmıştır.

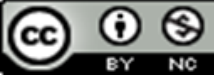

